UDC 633.63: 631

(C) 2016

L. Prysiazhniuk, Candidate of Agricultural Sciences

O., Shovgun, L. Korol, S. Goncharova, I. Korovko, A. Kostenko

Ukrainian Institute of Plant Variety Examination

\title{
ASSESSMENT OF NEW CULTIVARS OF SOYA BEAN ACCORDING TO ECONOMIC VALUABLE INDEXES
}

The purpose. To evaluate modern cultivars of soya bean of early ripening group by protein content, oleaginousness, oil and protein yield, mass of 1000 seeds and productivity by means of cluster analysis with the purpose to fix differences of probed cultivars. Methods. Field, laboratory, method of cluster analysis. Results. New cultivars of soya bean are studied according to the complex of economic valuable attributes by means of cluster analysis. Conclusions. It is fixed that to decrease the risks caused by adverse conditions of growing it is expedient to apply in conditions of one farm of cultivars of soya bean which are not similar and differently react to conditions of growing.

Key words: soya bean of early ripening group, soil-climatic zone, cluster analysis.

Introduction. Among legume crops soybean (Glycine max (L.) Merr.) occupies an exceptional position, which is primarily due to peculiarities of its seeds' biochemical composition: with high protein content from 30 to $45 \%$ comprising to $24 \%$ of oil [11]. The main objective of soybean breeding at the present stage is to create highly adaptable varieties that can maximize the potential of the crop, combined with high quality seeds and products [1].

Analysis of recent research and publications. Today a large number of new varieties is characterized by a wide ecological adaptability and suitable for growing in different soil and climatic conditions. According to scientists it is know that early varieties of soybeans are good precursors under winter crops due to the accumulation of nitrogen in the available form in the soil, improve soil structure and give opportunity for the early release of the fields, which positively affects the soil preparation $[3 ; 1 ; 2]$. Depending on the variety biology and environmental conditions soybean varietal 
characteristics are defined. The usage of early ripening varieties enables well-timed ripening and getting certified seeds without additional costs for revision. In this regard, topical are research of a new varieties of early ripening soybean within the frame of agronomic performance.

The purpose of work. To rate early modern varieties of soybeans within the context of protein and oil content, oil and protein collecting, with mass of 1000 seeds and productivity using cluster analysis to establish the differences between the studied varieties.

Research methods. In field trials conducted in four institutions of the governmental protection of right on the plant varieties, which are located in different soilclimatic zones (Vinnitsa, Dnepropetrovsk and Poltava research stations) during 20112014. In accordance with the method of the governmental scientific and technical expertise and qualification (technical) examination of plant varieties with determination of suitability for distribution, the total area of the experimental plot was $35 \mathrm{~m}^{2}$, accounting - $25 \mathrm{~m}^{2}$, three-time repetition, randomized placement of plots [6]. Laboratory tests conducted in the laboratory for definition of biochemical and technological parameters of the seeds' quality in Ukrainian Institute of Plant Variety Examination according to the "Methodology of the governmental scientific and technical expertise. Methods for the determination of quality in crop production " [5; 6].

For the new soybean varieties evaluation that have been included in the State Register of varieties suitable for dissemination in Ukraine in 2014-2015 according to the main agronomic characteristics cluster analysis was used, since this method, unlike most mathematical and statistical methods without imposes no restrictions on the type of the object and allows us to consider a lot of input data of almost any nature. [12] In our studies, we used soy varieties of early ripening (Table 1 ).

Table 1.

\section{List of studied soybean varieties}

\begin{tabular}{|l|c|c|c|c|}
\hline Item & $\begin{array}{c}\text { Name of } \\
\text { the } \\
\text { variety }\end{array}$ & $\begin{array}{c}\text { Year of } \\
\text { registration }\end{array}$ & $\begin{array}{c}\text { Recommended } \\
\text { zone for } \\
\text { growing }\end{array}$ & Declarant \\
\hline 1. & Triada & 2015 & S, FS, F & $\begin{array}{c}\text { Institute of Feed Research and } \\
\text { Agriculture of Podillya in National } \\
\text { Academy of Agricultural Sciences of }\end{array}$ \\
\hline
\end{tabular}




\begin{tabular}{|c|c|c|c|c|}
\hline & & & & Ukraine \\
\hline 2. & NS Zenit & 2015 & FS, F & $\begin{array}{c}\text { Institute of Crop Farming and } \\
\text { Vegetables Production, Novi Sad, } \\
\text { Serbia Republic } \\
\text { Foreign company "NS SEME- } \\
\text { UKRAYINA" }\end{array}$ \\
\hline 3. & $\begin{array}{l}\text { Diadema } \\
\text { Podillya }\end{array}$ & 2015 & $\mathrm{~S}, \mathrm{~F}$ & $\begin{array}{c}\text { Institute of Feed Research and } \\
\text { Agriculture of Podillya in National } \\
\text { Academy of Agricultural Sciences of } \\
\text { Ukraine }\end{array}$ \\
\hline 4. & Sofia & 2015 & S, FS, F & $\begin{array}{l}\text { Institute of Irrigational Agriculture in } \\
\text { National Academy of Agricultural } \\
\text { Sciences of Ukraine }\end{array}$ \\
\hline 5. & Kyoto & 2014 & S, FS, F & Semencess Prograin Inc. \\
\hline 6. & Cassidi & 2014 & S, FS, F & Semencess Prograin Inc. \\
\hline 7. & Rapsodiya & 2014 & S, FS, F & $\begin{array}{c}\text { Institute of Oil Crops in National } \\
\text { Academy of Agricultural Sciences of } \\
\text { Ukraine }\end{array}$ \\
\hline 8. & Dana & 2014 & FS, F & Strube GmbH \& Co. KG \\
\hline 9. & Vidra & 2014 & S, FS, F & Strube GmbH \& Co. KG \\
\hline 10. & Biser & 2014 & S, FS, F & Strube GmbH \& Co. KG \\
\hline
\end{tabular}

Investigated varieties of early ripening soybean group within the frame of morphological characteristics are different according to the type of growth, the main stem color, type and color of lateral leaf, shape and color of seed. The growing season varies depending on growing areas [8; 9; 10].

Results. Governmental scientific and technical examination of plant varieties based on experimental evaluations of morphological, biological and agronomic traits of plant varieties with the aim of determination its suitability for usage in certain 
environmental conditions, in compliance with accepted technologies and methods of research.

For the studied soybean varieties protein and oil content, collection of oil and protein mass of 1000 seeds and productivity were estimated. Table 2 shows the average values of protein and oil content, and yield soybean varieties in terms of steppe, foreststeppe and forest area during 2011-2014.

Table 2

\section{Indicators of yield, protein and oil content of soybean varieties in different soil-climatic zones}

\begin{tabular}{|c|c|c|c|c|c|c|c|c|c|c|}
\hline \multirow{2}{*}{$\begin{array}{l}\text { Item } \\
\text { No. }\end{array}$} & \multirow[t]{2}{*}{ Variety } & \multicolumn{3}{|c|}{ Protein content, \% } & \multicolumn{3}{|c|}{ Oilness, \% } & \multicolumn{3}{|c|}{ Yield, t/ha } \\
\hline & & 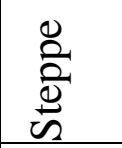 & 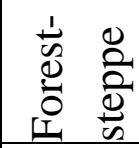 & 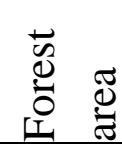 & 节 & 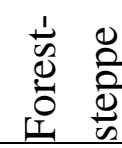 & 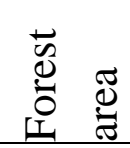 & 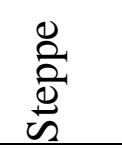 & 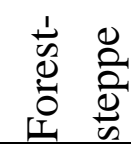 & 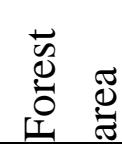 \\
\hline 1. & Kioto & 41,03 & 39,43 & 41,13 & 20,50 & 21,03 & 19,93 & 20,57 & 28,97 & 33,83 \\
\hline 2. & Cassidi & 43,10 & 41,13 & 41,57 & 19,00 & 19,47 & 19,13 & 19,27 & 27,28 & 31,00 \\
\hline 3. & Rapsodiya & 39,13 & 37,92 & 37,97 & 20,67 & 21,53 & 20,17 & 17,10 & 24,20 & 28,67 \\
\hline 4. & Dana & 40,20 & 38,78 & 39,07 & 20,33 & 20,97 & 19,73 & 7,33 & 23,07 & 29,60 \\
\hline 5. & Vidra & 41,80 & 39,10 & 40,37 & 20,37 & 20,58 & 19,67 & 7,53 & 24,60 & 32,10 \\
\hline 6. & Biser & 41,83 & 40,47 & 40,77 & 19,77 & 20,50 & 19,03 & 9,03 & 21,45 & 28,03 \\
\hline 7. & Triada & 35,63 & 38,05 & 39,23 & 20,33 & 21,68 & 20,23 & 10,20 & 21,77 & 29,07 \\
\hline 8. & NS Zenit & 37,80 & 38,55 & 38,80 & 22,03 & 20,18 & 18,90 & 11,50 & 22,42 & 28,60 \\
\hline 9. & $\begin{array}{l}\text { Diadema } \\
\text { Podillya }\end{array}$ & 41,13 & 39,32 & 40,13 & 20,20 & 21,58 & 20,03 & 9,00 & 21,02 & 27,20 \\
\hline 10. & Sofia & 38,80 & 37,10 & 37,30 & 20,60 & 21,15 & 20,07 & 11,77 & 19,05 & 25,40 \\
\hline
\end{tabular}

According to the research it was discovered that Dana and Vidra varieties had the lowest yields in the steppe zone - 7,33 and 7,53 t/ha and protein content 40.20 and 
$41.80 \%$, respectively. For those varieties in the steppe zone a high level of the oil content was distinctive - 20.33 and 20.37\%, respectively. Soybean varieties Kyoto and Vidra provided yield formation at the level 33.83 and $32.10 \mathrm{t} / \mathrm{ha}$ in forest area, oil content of Kyoto variety was the biggest in the steppe area and was $21.03 \%$. Protein content of this variety showed the highest level in steppe and forest areas 41.03 and $41.13 \%$, respectively.

The highest level of oil content - 21.58\% in forest-steppe zone demonstrated Triada variety with yield efficiency $-21.77 \mathrm{t} / \mathrm{ha}$ and protein content $-38.05 \%$. However, in terms of the steppe zone was noted low protein content - 35.63\%. Cassidy variety characterized by a high protein content in all soil-climatic zones $41,57-43,10 \%$ which was tested for years. There were also high rates of oil content $(19,00-19,47 \%)$ and productivity - 19,27-31,00 t/ha.

The effectiveness of cultivation of certain soybean varieties was estimated by integral indicators of oil collection and protein amount per hectare area. Also the mass of 1000 seeds determination was important, as these criteria affected the yield of seeds and square of the planting unit. Therefore, the formation of the recommendations for manufacturer, regarding the correct selection of varieties, the complex evaluation of varieties within the frame of agronomic performance is required.

To establish differences of studied early ripening soybean varieties according to the indicators of protein content, oil content, yield, weight of 1000 seeds, protein and oil collecting cluster analysis was performed using the computer program Statistica [4]. The classes grouping of studied soybean varieties was carried out by single bonds. Results of hierarchical classification presented in a phylogenetic tree in Fig. 1.

Based on the studies three clusters were identified. Thus, one of the clusters formed varieties Kyoto and Cassidy, the second one - Dana and Triada varieties, and the third - NS Zenit and Diadema Podillya varieties, indicating the similarity of these varieties. This similarity is caused by inheritance peculiarities of agronomic traits and is legitimate.

Rapsodiya variety was located in a nearby cluster, indicating its proximity to Kyoto and Cassidy variety. Varieties Vidra, Biser and Sofia were in clusters adjacent to the varieties Triada, NS Zenit and Diadema Podillya, as well it should be noted, that Sofia variety was the most remote of other varieties, which, in turn, speaks of its distinction. 
However, the fact should be noted that for a soybean varieties creation, which were in different clusters and differed by the complex agronomic traits caused by a genetic component of raw materials for crossing.

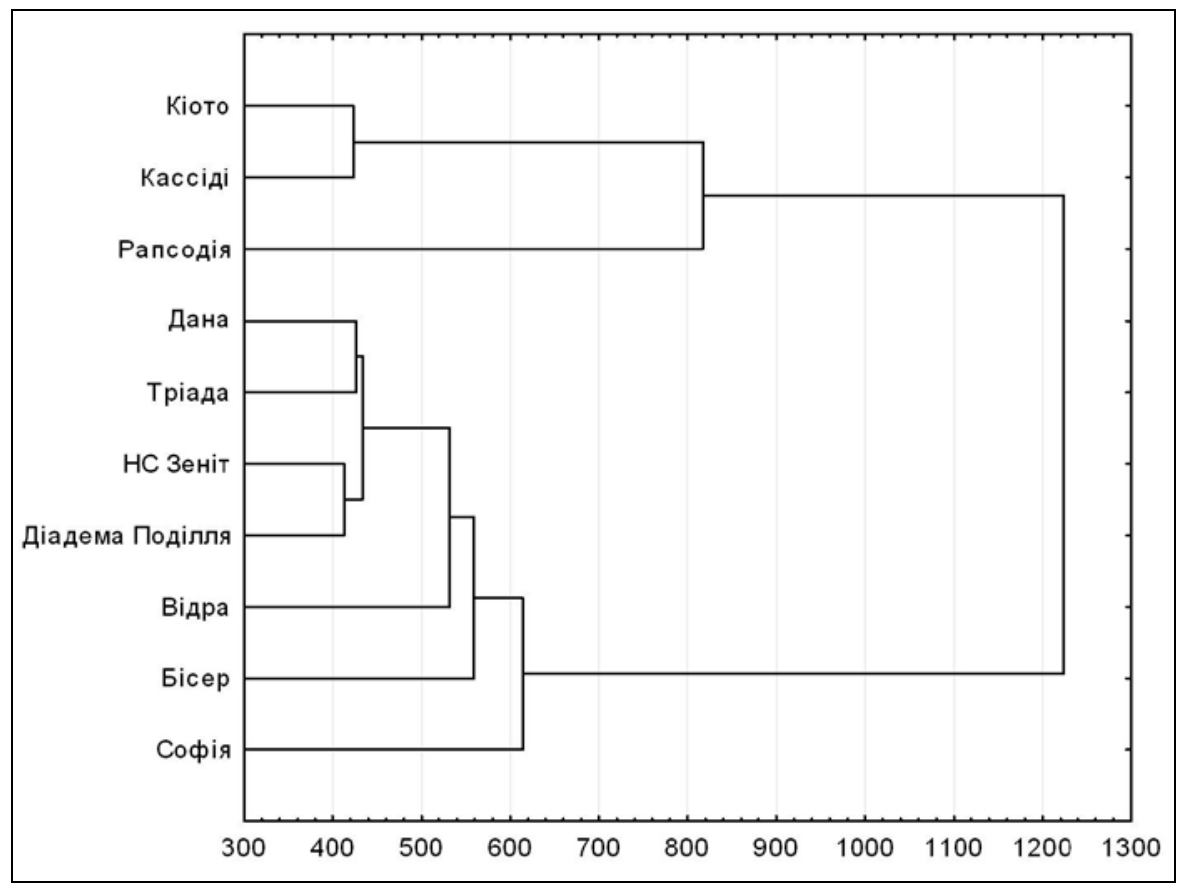

Fig. 1. Clustering soybean varieties by major agronomic characteristics for different soil and climatic zones

Conclusion. It was found that the best for growing in the Forest area were varieties Kyoto and Vidra, because besides high yield, they were characterized by high protein 41.13 and $40.37 \%$, respectively. For a forest-steppe zone was the best Triada variety, which showed the highest level of oil content $21.58 \%$, remained high yield and protein content.

Based on the studies it was discovered that as close by the complex of traits were clusters which formed soybean varieties Kyoto and Cassidy, Dana and Triada, NS Zenit and Diadema Podillya. There were no significant similarities between soybean varieties Rapsodiya, Vidra, Biser and Sofia.

So, according to conducted comprehensive assessment of studied soybean varieties with usage of cluster analysis it was discovered that the best varieties not belong to the same cluster. This indicates the possibility of growing them within one household for reducing risks associated with the effect of adverse conditions, as characterized by different response to the growing conditions and shows no similarity in agronomic traits. 


\section{Bibliography}

1. Bilyavs'ka L.H. Novyy rann'ostyhlyy sort soyi Antratsyt / L.H. Bilyavs'ka // Visnyk Poltavs'koyi derzhavnoyi ahrarnoyi akademiyi. - 2012. - \# 2. - S. 52-56.

2. Boyko O.O. Otsinka faktornoho vplyvu na valovyy zbir soyi metodom indeksnoho analizu / O.O.Boyko // Ekonomika i rehion. - 2012. - \# 4 (35). - S. 127-130.

3. Hlupak Z.I. Urozhaynist' i yakist' soyi sortiv rann'ostyhloyi hrupy v umovakh pivnichno-skhidnoyi chastyny Lisostep Ukrayiny / Z.I. Hlupak // Visnyk Sums'koho natsional'noho ahrarnoho universytetu. - 2013. - Vyp. 11 (26). - S. 100-103.

4. Mel'nyk A.V. Vykorystannya klasternoho analizu za pidboru sortiv i hibrydiv ripaku yaroho dlya vyroshchuvannya v livoberezhnomu Lisostepu Ukrayiny / A.V. Mel'nyk // VISNYK Poltavs'koyi derzhavnoyi ahrarnoyi akademiyi. - \# 4. 2013. - S. 611.

5. Metodyka derzhavnoyi naukovo - tekhnichnoyi ekspertyzy sortiv roslyn. Metody vyznachennya pokaznykiv yakosti produktsiyi roslynnytstva. - Kyyiv, 2011. - Vyp. \# 7. $-149 \mathrm{~s}$.

6. Metodyka kvalifikatsiynoyi (tekhnichnoyi) ekspertyzy sortiv roslyn z vyznachennya pokaznykiv prydatnosti do poshyrennya v Ukrayini. - Kyyiv, 2011. Vyp. \# 1. - 102 s.

7. Oldenderfer M.S. Klasternыy analyz. Faktornыy, dyskrymynantnыy y klasternыy analyz / M.S. Oldenderfer, R.K. Blэshfyld; [per. s anhl. pod. red. Y.S. Enyukova]. - M.: Fynansы y statystyka, 1989. - 215 s. 
8. Okhorona prav na sorty roslyn: Byuleten' / Derzhavna veterynarna ta fitosanitarna sluzhba Ukrayiny, Ukrayins'kyy instytut ekspertyzy sortiv roslyn. - 2014. - Vyp. 4 (Ch. 1). $-506 \mathrm{~s}$.

9. Okhorona prav na sorty roslyn: Byuleten' / Derzhavna veterynarna ta fitosanitarna sluzhba Ukrayiny, Ukrayins'kyy instytut ekspertyzy sortiv roslyn. - 2015. - Vyp. 1 (Ch. 2) (spetsvypusk). - $1026 \mathrm{~s}$.

10. Okhorona prav na sorty roslyn: Byuleten' / Derzhavna veterynarna ta fitosanitarna sluzhba Ukrayiny, Ukrayins'kyy instytut ekspertyzy sortiv roslyn. - 2014. - Vyp. 2 (Ch. 1.). $-648 \mathrm{~s}$.

11. Sherepitko D.V. Otsinka lokusu Rsv1 yak determinanty stiykosti do mistsevykh shtamiv virusu mozayiky soyi / D.V. Sherepitko, V.V. Sherepitko // Dopovidi Natsional'noyi akademiyi nauk Ukrayiny. - 2011. - \# 10. - S. 143-147.

12. Everitt B.S. Cluster Analysis 5th Edition. / B. S. Everitt, S. Landau, M. Leese, D. Stahl. - King"s College London, UK, 2011. 